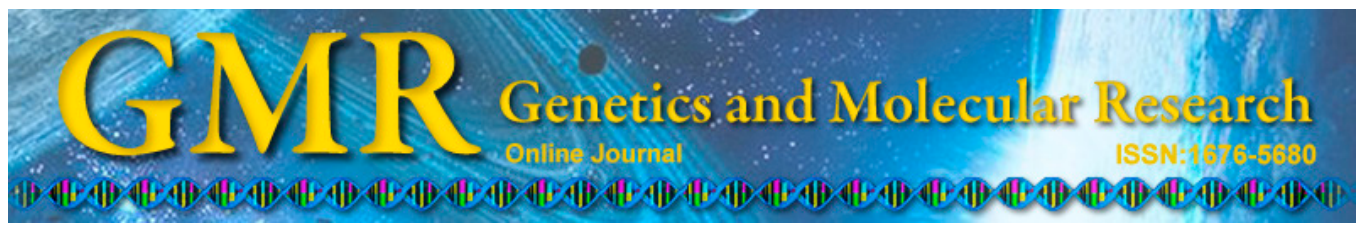

\title{
Genetic control of the number of leaves above the ear in maize
}

\author{
A.I. Freire ${ }^{1}$, K.O.G. Dias ${ }^{1}$, L.B.V. Oliveira ${ }^{1}$, R.S. Nalin ${ }^{1}$, F.L. Guedes ${ }^{2}$ \\ and J.C. Souza ${ }^{1}$ \\ ${ }^{1}$ Departamento de Biologia, Universidade Federal de Lavras, \\ Lavras, MG, Brasil \\ ${ }^{2}$ Embrapa Caprinos e Ovinos, Sobral, CE, Brasil
}

Corresponding author: R.S. Nalin

E-mail: rafael.nalin01@gmail.com

Genet. Mol. Res. 14 (1): 1318-1323 (2015)

Received May 8, 2014

Accepted October 25, 2014

Published February 13, 2015

DOI http://dx.doi.org/10.4238/2015.February.13.11

\begin{abstract}
In this study, we examined the genetic control of the number of leaves above the first ear in maize. The $\mathrm{F}_{2}$ generations and the backcrosses were obtained from 2 contrasting lines for this trait. All generations were assessed in a completely randomized block design with 2 replications. The number of leaves above the ear was counted when the plants were in the tasseling stage at the level of plants per plot. Mean and variance components were estimated using the weighted least square method. We observed a predominance of non-additive effects in the genetic control of number of leaves above the ear. These results indicate that this trait shows high heritability.
\end{abstract}

Key words: Genetic components; Leaf area; Zea mays L. 


\section{INTRODUCTION}

Leaf area is closely related to the photosynthetic capacity of maize plants. Thus, reductions in leaf area can substantially alter physiological activity, reducing plant metabolism and grain yield (Alvim et al., 2011). In addition, the photosynthetic potential of a crop can be inferred based on leaf area, which depends on leaf number and size as well as development stage of the plants.

Generally, leaf area increases up to a limit, and then decreases because of leaf senescence (Brito et al., 2011). Quickly reaching the maximum leaf area index and maintaining this state for a long period will result in greater yield (Manfron et al., 2003). Recent studies showed that removing leaves above the ear results in grain yield losses (Lima et al., 2010; Alvim et al., 2010; Khaliliaqdam et al., 2012), while removing half or all leaves below the ear has inexpressive consequences with respect to these losses. Alvim et al. (2010) found that leaves located above the ear provide most of the photoassimilates necessary for grain filling in the ear.

According to Camacho et al. (1995), approximately 50\% of carbohydrates accumulating in maize kernels originate from the leaves located in the upper third of the stalk, approximately $30 \%$ from leaves located in the middle third, and the remaining from the leaves distributed along the base. According to Mock and Pearce (1975), plants with firm and vertically directed leaves above the ear are in accordance with the ideotype of this crop. Recent studies have also shown that these characteristics are important in breeding programs in which a main objective is increasing the number of plants per hectare with hybrids/cultivars of low plant height (Combs and Bernardo, 2013). Despite the importance of number of leaves above the ear, there have been few studies examining the genetic control of this trait. Understanding the genetic control of leaf number above the ear is important for beginning a breeding program selecting for this characteristic to develop an ideotype of plants that maximize yield.

In this study, we examined the variability for this trait. Contrasting genotypes for number of leaves above the first ear are frequently observed in experimental fields of maize lines, allowing studies to determine the genetic control of this trait.

In light of the above, this study was carried out to understand the genetic control of the number of leaves above the first ear in maize.

\section{MATERIAL AND METHODS}

The experiment was conducted in the experimental area of the Department of Biology of Universidade Federal de Lavras in the city of Lavras, located in the south of Minas Gerais, Brazil. The altitude of the location is $910 \mathrm{~m}$, with geographic coordinates of $21^{\circ} 58^{\prime}$ latitude south and $45^{\circ} 22^{\prime}$ longitude west.

To study the genetic control of the number of leaves above the ear in maize, 2 lines differing in this trait were identified from the maize breeding program of Department of Biology of Universidade Federal de Lavras. The first line (Lb) has an average of 3 leaves above the ear and the second line (Lf) has an average of 7 leaves (Figure 1). From these 2 lines, the $\mathrm{F}_{2}$ generations and the backcrosses with both lines $\left(\mathrm{BC}_{1}\right.$ and $\mathrm{BC}_{2}$ ) were obtained. 


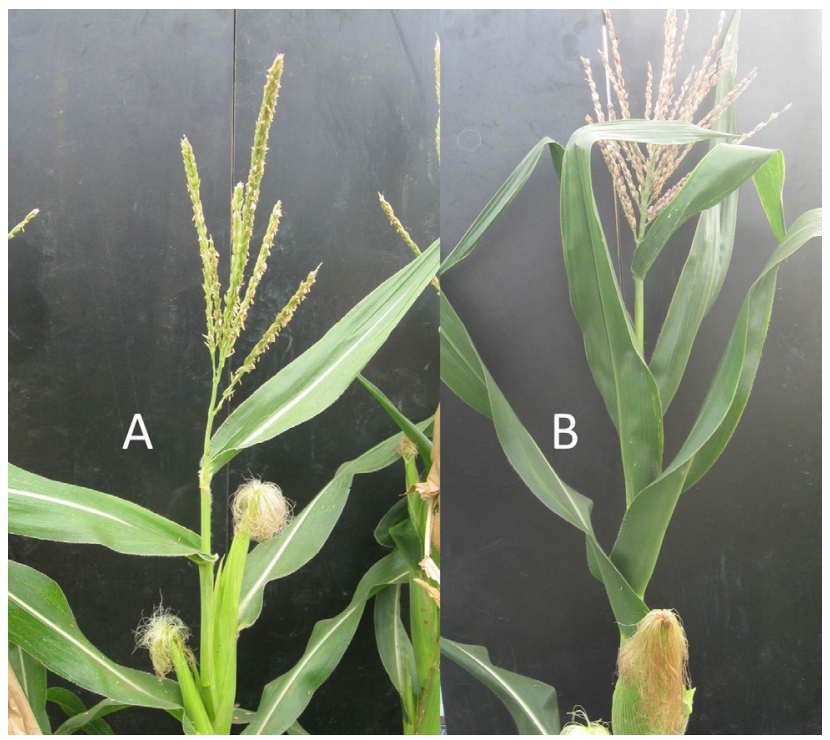

Figure 1. Maize breeding program lines from UFLA. A. Maize line with only a few leaves above the ear. B. Maize line with a large number of leaves above the ear. Lavras, MG, Brazil.

The parent lines ( $\mathrm{Lf}$ and $\mathrm{Lb})$ and the segregating populations $\left(\mathrm{F}_{2}, \mathrm{BC}_{1}\right.$, and $\left.\mathrm{BC}_{2}\right)$ were assessed in a completely randomized block experimental design with 2 replications. The plots were sown in November 2012 and consisted of two 4-m rows for the lines (32 plants), eight 4-m rows in the $\mathrm{F}_{2}$ generation (128 plants), and six 4-m rows in the $\mathrm{BC}_{1}$ and $\mathrm{BC}_{2}$ generations (96 plants). Studies estimating genetic control in maize traits have used a similar number of plants to represent the different populations (Toledo et al., 2011; Entringer et al., 2014). Between-plant spacing was $0.25 \mathrm{~m}$, with $0.60 \mathrm{~m}$ between rows. All recommended crop management operations were performed to provide the best conditions for plant development.

When the plants were in the tasseling stage, the number of leaves above the ear was assessed at the level of plants per plot. After analyzing variance, the mean components were estimated using the weighted least squares method with the following model: $\hat{\beta}=\left(\mathrm{C}^{\prime} \mathrm{NS}^{-1} \mathrm{C}^{-1}\left(\mathrm{C}^{\prime} \mathrm{NS}^{-1} \mathrm{Y}\right)\right.$ in which $\hat{\beta}$ was the vector of the parameters ( $\hat{m}$ was estimator of the mean; $\hat{a}$ was the estimator of the deviations of the homozygote in relation to the mean; and $\hat{d}$ was the estimator of the deviations of the heterozygote in relation to the mean); $C$ was the design matrix, consisting of the overall mean, contribution of homozygous loci, and of heterozygous loci; $N$ was the matrix of the number of plants assessed within each generation; $S$ was the matrix of the variances associated with the generations; and $Y$ was the vector of the mean values observed in the generations (Ramalho et al., 2012).

Components of variance were estimated using the iterative weighted least squares method using the following model: $\hat{\beta}=\left(C^{\prime} Z^{-1} C\right)^{-1}\left(C^{\prime} Z^{-1} Y\right)$, in which $\hat{\beta}$ was the vector of the parameters ( $\hat{\sigma}_{A}^{2}=$ estimate of additive genetic variance; $\hat{\sigma}_{D}^{2}=$ estimate of dominance genetic variance; and $\hat{\sigma}_{E}^{2}=$ estimate of environmental variance); $C$ was the matrix of the model, consisting 
of additive, dominance, and environmental variance within each generation; $Z$ was the weighting matrix of the observations, and $Y$ was the vector of the variances observed within each population (Ramalho et al., 2012).

Estimates of broad heritability patterns $\left(\hat{\mathrm{h}}_{\mathrm{A}}^{2}\right)$ were obtained using expressions described by Ramalho et al. (2012). All estimates were obtained using the R software (R Development Core Team, 2013).

\section{RESULTS AND DISCUSSION}

The lines $\mathrm{Lf}$ and $\mathrm{Lb}$ were contrasting for the leaf number trait; i.e., they differed in the number of leaves above the ear, with the lines $\mathrm{Lf}$ and $\mathrm{Lb}$ exhibiting phenotypic mean values of 6.90 and 3.45, respectively (Table 1). According to Cruz et al. (2012), contrast between the parent lines is essential for achieving greater precision in genetic analyses.

\begin{tabular}{|c|c|c|c|}
\hline Population & No. of plants & Mean & Variance \\
\hline $\mathrm{Lf}$ & 64 & 6.90 & 0.4672 \\
\hline $\mathrm{Lb}$ & 58 & 3.45 & 0.4573 \\
\hline $\mathrm{F}_{2}$ & 246 & 6.57 & 0.6870 \\
\hline $\mathrm{BC}_{1}$ & 180 & 7.10 & 0.5374 \\
\hline $\mathrm{BC}_{2}^{1}$ & 187 & 5.71 & 0.4915 \\
\hline
\end{tabular}

The mean value of the $\mathrm{F}_{2}$ generation (6.57) was greater than the mean value of the parents (5.17), indicating that the genes involved have non-additive allelic interaction, i.e., the heterozygous loci, have a greater effect than homozygous loci. Backcrosses showed the expected behavior. When the line with the greatest number of leaves (Lf) was used as the recurrent parent, the mean value of $\mathrm{BC}_{1}$ generally approached the maximum number of leaves above the ear. However, when the line with the lowest number of leaves (Lb) was used as the recurrent parent, the mean value of $\mathrm{BC}_{2}$ was generally lower, but higher than the mean value of the parents. Estimates of variances were consistent with expected values, in which the $\mathrm{F}_{2}$ generation showed the greatest variance (Table 1).

Estimates of the mean components are shown in Table 2. The coefficient of determination $\left(\mathrm{R}^{2}\right)$ was 0.99 , indicating that the additive dominance model without epistasis fit the data for the trait under study. Component â, which estimates the deviation of the homozygotes compared to the mean, and component $\hat{d}$, which estimates the deviation of the heterozygotes compared to the mean, differed from 0 . The estimate of component $\hat{d}$ was greater than that of component $\hat{a}$, indicating again the predominance of the non-additive allelic interaction.

Table 2. Mean components, associated errors, and coefficient of determination of the model $\left(\mathrm{R}^{2}\right)$ of the number of leaves above the ear, obtained in the 2012/2013 crop season in Lavras, MG, Brazil.

\begin{tabular}{lcr}
\hline Parameters & Estimate & Standard error \\
\hline$\hat{m}$ & 4.6 & \pm 0.05 \\
$\hat{\mathrm{a}}$ & 1.60 & \pm 0.04 \\
$\hat{d}$ & 2.60 & \pm 0.13 \\
$\mathrm{R}^{2}$ & 0.99 & \\
\hline
\end{tabular}


Estimates of the components of variance are shown in Table 3. The additive dominance model without epistasis fit the data well, as shown by the coefficient of determination of 0.99 . Estimates of additive variance and of dominance variance differed from 0 . These results agree with those of Lima et al. (2010), who found different behavior among genotypes tested for number of leaves above the ear.

Table 3. Components of variances, associated errors, and coefficient of determination of the model $\left(\mathrm{R}^{2}\right)$ of the number of leaves above the ear, obtained in the 2012/2013 crop season in Lavras, MG, Brazil.

\begin{tabular}{lcc}
\hline Parameters & Estimate & Standard error \\
\hline$\hat{\sigma}_{E}^{2}$ & 0.46 & \pm 0.05 \\
$\hat{\sigma}_{A}^{2}$ & -0.66 & \pm 0.23 \\
$\hat{\sigma}_{D}^{2}$ & 0.89 & \pm 0.28 \\
$\hat{\mathrm{h}}_{A}^{2}$ & 0.66 & \\
$\mathrm{R}^{2}$ & 0.99 & \\
\hline
\end{tabular}

These observations are interesting from the perspective of genetic breeding as an understanding of genetic control is fundamental for defining breeding strategies. In the present study, the additive variance was negative, which indicates that this value is equal to zero. Nevertheless these results indicate the importance of dominance in the expression of this trait. Hybrids are needed to assess traits with partial dominance, whereas traits with additive effects are desirable because of the ease of selectionand the potential totransferfavorableallelestogenotypes ofinterest (Ramalho et al., 2012).

Bernardo (2010) found that the estimate of dominance variance should conceptually be of a lower magnitude because $\hat{\sigma}_{D}^{2}$ is estimated as the deviation from regression of the genotypic values and the number of alleles. As the estimator is of least squares, the $\hat{\sigma}_{D}^{2}$ should be minimal, i.e., although the estimate is underestimated, the $\hat{\sigma}_{D}^{2}$ is still near $\hat{\sigma}_{A}^{2}$. This result indicates the presence of a non-additive effect in genetic control of the trait. Studies estimating genetic control of other traits in maize, such as production components, revealed predominance of the dominance effect in expression of the trait (Srdić et al., 2007; Toledo et al., 2011).

To increase the efficiency in using this information for the genetic control of the number of leaves above the ear, it is necessary to verify the effect of the environment on this trait. Heritability is a genetic parameter that can be used to predict gains from selection. In this study, $\hat{\mathrm{h}}_{\mathrm{A}}^{2}$ was $65.92 \%$, which is of high magnitude, indicating a little influence of the environment on expression of the trait, wich may facilitate gains from selection steps. Nevertheless, previous reports on the estimates of genetic components of this trait are limited. Therefore, additional studies are necessary to determine the best breeding strategy to achieve the ideotype of plants with the greatest number of leaves above the ear.

\section{CONCLUSIONS}

There is predominance of non-additive effects in the genetic control of the number of leaves above the ear. The number of leaves above the ear shows high heritability.

\section{ACKNOWLEDGMENTS}

Research supported by CNPq, CAPES, and FAPEMIG. 


\section{REFERENCES}

Alvim KRT, Brito CH, Brandão AM, Gomes LS, et al. (2010). Quantificação da área foliar e efeito da desfolha em componentes de produção de milho. Ciência Rural 4: 1017-1022.

Alvim KRT, Brito CH, Brandão AM, Gomes LS, et al. (2011). Redução de área foliar em plantas de milho na fase reprodutiva. Rev. Ceres 58: 413-418.

Bernardo R (2010). Breeding for Quantitative Traits in Plants. 2nd edn. Stemma Press, Woodbury.

Brito CH, Silveira DL, Brandão AM and Gomes LS (2011). Redução de área foliar em milho em região tropical no Brasil e os efeitos em caracteres agronômicos. Interciencia 36: 291-295.

Camacho RG, Garrido O and Lima MG (1995). Caracterizacion de nueve genótipos de maiz (Zea mays L.) em relacion a area foliar y coeficiente de extincion de luz. Sci. Agric. 52: 294-298.

Combs E and Bernardo R (2013). Genome wide selection to introgress semi dwarf maize germplasm into U.S. corn belt dents. Crop Sci. 53: 1427-1436.

Cruz CD, Regazzi AJ and Carneiro PCS (2012). Modelos Biométricos Aplicados ao Melhoramento Genético. UFV, Viçosa.

Entringer GC, Guedes FL, Oliveira AA and Nascimento JP (2014). Genetic control of leaf curl in maize. Genet. Mol. Res. 13: $1672-1678$.

Khaliliaqdam N, Soltani A, Mir-Mahmoodi T and Jadidi T (2012). Effect of leaf defoliation on some agronomical traits of corn. World Appl. Sci. J. 20: 545-548.

Lima TG, Pinho RGV, de Andrade Rezende Pereira JL and De Brito AH (2010). Consequências da remoção do limbo foliar em diferentes estádios reprodutivos da cultura do milho em duas épocas de semeadura. Bragantia 69: 563-570.

Manfron PA, Dourado Neto D, Pereira AR and Bonnecarrére RAG (2003). Model of leaf area index of maize. Rev. Bras. Agrometeorologia 11: 333-342.

Mock JJ and Pearce RB (1975). An ideotype of maize. Euphytica 24: 613-623.

R Development Core Team (2013). R: a Language and Environment for Statistical Computing. R Foundation for Statistical Computing, Vienna.

Ramalho MAP, Abreu AFB, Santos JB and Nunes JAR (2012). Aplicações da Genética Quantitativa no Melhoramento de Plantas Autógamas. 1st edn. Editora UFLA, Lavras.

Srdić J, Pajić Z and Drinić-Mladenović S (2007). Inheritance of maize grain yield components. Maydica 52: 261-264.

Toledo FH, Ramalho MA, Abreu GB and de Souza JC (2011). Inheritance of kernel row number, a multicategorical threshold trait of maize ears. Genet. Mol. Res. 10: 2133-2139. 